WIDER Working Paper 2021/8

\title{
Premature deindustrialization and income inequality in middle-income countries
}

Rekha Ravindran and Suresh Babu M*

January 2021 
Abstract: This paper examines the income inequality implications of a 'premature deindustrialization' trend in middle-income countries. To identify the premature deindustrialization phase, we arrive at five conditions based on the trends in employment and value-added share of manufacture. Among these five conditions, the first and second examine the deindustrialization pattern in economies. The last three classify the identified deindustrialization phase as premature or not. We apply panel fixed-effects and bootstrap-corrected dynamic fixedeffects models to empirically examine the relationship between premature deindustrialization and income inequality. Our findings suggest that income inequality rises with premature deindustrialization if the displaced workers are absorbed into low-productivity and informal market services (especially with employment increase in non-business market services such as trade, transport, hotels, and accommodation activities). In contrast, if high-productivity nonmarket services are the dominant employment provider, this helps to reduce income inequality even in the presence of premature deindustrialization.

Key words: premature deindustrialization, income inequality, middle-income countries, manufacturing employment, service sector employment, structural transformation

JEL classification: C23, O10, O1, O47

Acknowledgements: The authors gratefully acknowledge Simone Schotte, Kunal Sen, Michael Danquah, and Carlos Gradín for their valuable feedback and comments that helped to shape the paper. We thank the UNU-WIDER team for extending constant support throughout the research period. A preliminary version of the paper was presented at the 2019 UNU-WIDER Development Conference on Transforming Economies for Better Jobs in Bangkok. We are also grateful for the constructive suggestions from the participants at the conference.

\footnotetext{
* Both authors: Department of Humanities and Social Sciences, Indian Institute of Technology Madras, Chennai, India; corresponding author: Rekha Ravindran, rekha181990@gmail.com
}

This study has been prepared within the UNU-WIDER project Structural transformation- the old and new paths to economic development.

Copyright (C) UNU-WIDER 2021

Information and requests: publications@wider.unu.edu

ISSN 1798-7237 ISBN 978-92-9256-942-6

https://doi.org/10.35188/UNU-WIDER/2021/942-6

Typescript prepared by Luke Finley.

United Nations University World Institute for Development Economics Research provides economic analysis and policy advice with the aim of promoting sustainable and equitable development. The Institute began operations in 1985 in Helsinki, Finland, as the first research and training centre of the United Nations University. Today it is a unique blend of think tank, research institute, and UN agency — providing a range of services from policy advice to governments as well as freely available original research.

The Institute is funded through income from an endowment fund with additional contributions to its work programme from Finland, Sweden, and the United Kingdom as well as earmarked contributions for specific projects from a variety of donors.

Katajanokanlaituri 6 B, 00160 Helsinki, Finland

The views expressed in this paper are those of the author(s), and do not necessarily reflect the views of the Institute or the United Nations University, nor the programme/project donors. 
Structural transformation is capable of enhancing growth when the labour transition occurs from low-productivity to high-productivity sectors. ${ }^{1}$ During the process of structural transformation, economies often have to face a trade-off between economic growth and income inequality (Kuznets 1955). However, recent literature on structural transformation highlights that labour transition to non-agriculture sectors increases income inequality only if the dominant employment provider is the service sector and not the manufacturing sector (Baymul and Sen 2020; Jaumotte et al. 2013; Sarma et al. 2017; Sumner and London 2017). This finding generates concern for middle-income economies, as many of them are experiencing labour transition towards the service sector along with a fall in manufacturing employment. ${ }^{2}$ This shift in labour towards services before experiencing industrialization is known as 'premature deindustrialization' (Dasgupta and Singh 2006; Rodrik 2016; UNCTAD 2003). ${ }^{3}$ In this study, we analyse how this premature deindustrialization trend, coupled with a service-driven labour transition, alters the level of income inequality in middle-income economies.

To identify the premature deindustrialization episodes in middle-income countries, we arrive at a set of five conditions. Among the five conditions, the first and second filter out cases of deindustrialization by considering the trends in both employment and value-added share of manufacture. The last three conditions distinguish 'premature' cases from general cases of deindustrialization. According to Rodrik (2016), the 'premature' aspect to deindustrialization occurs in two senses. First, developing economies experience deindustrialization at considerably lower levels of income compared with advanced economies. Second, the process of deindustrialization in the initial stages of development is premature, as the economy might thereby lose a channel via which it could have gained rapid economic growth through the manufacturing sector. Moreover, Felipe et al. (2019) specify that the inability to meet a historically derived threshold for the manufacturing share (in employment) gives early deindustrialization its 'premature' character. Following these arguments, to capture the 'premature' factor of deindustrialization in the last three conditions, we define threshold levels in terms of income, manufacturing employment share, and manufacturing value-added share.

We apply panel fixed-effects and bootstrap-corrected dynamic fixed-effects techniques to analyse the relationship between premature deindustrialization and inequality in middle-income countries. For income inequality data, we depend on the World Income Inequality Database (WIID; UNUWIDER 2020). The International Labour Organization (ILO; ILOSTAT 2020) and the United Nations Statistic Division (UNSD 2020) National Aggregates database provide the sectoral employment and value-added data, respectively. We also use the World Bank's (2020) World

\footnotetext{
${ }^{1}$ Structural transformation implies the movement of labour and other resources from one sector to another during the process of economic development (McMillan et al. 2014). In the traditional pattern of structural transformation, labour movement occurs from agriculture to industry in the initial phase of economic growth. Later, as the economy reaches higher stages of development, the shift in labour occurs from industry to the service sector. Generally, advanced economies experience this pattern of structural transformation.

2 The World Bank country classification (fiscal year 2021) specifies that middle-income countries are those with GNI (gross national income) per capita of between US\$1,036 and \$12,535 in 2019. High-income countries are those with GNI per capita of $\$ 12,536$ or more. Low-income countries are those with GNI per capita of \$1,035 or less.

3 Deindustrialization generally implies a fall in the manufacturing employment (or value-added) share in total employment (or total output) after reaching a peak. Hence, it follows a hump-shaped relationship with income level.
} 
Development Indicator (WDI) database for the empirical analysis. For the analysis, we group service activities into market services (International Standard Industry Classification/ISIC Rev. 4 G-M) and non-market services (ISIC Rev. 4 N-S). Non-market services include activities such as public administration, defence, education, health, and other service activities. We further classify market services into non-business market services (ISIC Rev. 4 G-J) and business market services (ISIC Rev. $4 \mathrm{~K}-\mathrm{M}) .{ }^{4}$ Non-business market services include more informal and low-productivity activities such as trade, transport, food, and accommodation. Business market services consist of more formal and high-productivity activities such as banking, finance, and administrative and other professional service activities. Our empirical findings suggest that if premature deindustrialization leads to labour absorption in non-business market services, it increases overall income inequality. In contrast, if the employment increase is in non-market services, it reduces income inequality in the economy. Thus, if high-productivity service activities are the dominant labour-absorbing sector in the economy, structural transformation (especially an early deindustrialization trend) need not generate a trade-off between growth and inequality.

The rest of the paper consists of the following sections. Section 2 proposes a method to detect premature deindustrialization. Section 3 provides some stylized facts about the relationship between structural transformation and inequality in middle-income countries. Section 4 describes the empirical strategy and data. Section 5 documents the empirical findings and discussion, and Section 6 concludes the paper.

\section{Premature deindustrialization: identification method}

In this section, we attempt to identify economies that are experiencing a phase of premature deindustrialization. Traditionally, the fall in either manufacturing employment share (in total employment) or manufacturing value-added share (in total output) represents the measure for deindustrialization (for example, see Palma 2014; Rowthorn and Ramaswamy 1999; Tregenna 2009). Tregenna (2013) suggests that an economy might experience a fall in manufacturing employment due to the rise in labour productivity (caused by an increase in skills and technology or labour-displacing capital intensification). Hence, a falling employment share of manufacturing, along with a similar trend in value-added share, is necessary to identify a deindustrialization phase. For instance, China has experienced a steep fall in manufacturing employment in decade to 2020, whereas its value-added share of manufacturing is still on the rise (see Appendix Figure A1). In this case, if we considered only the fall in manufacturing employment share we might classify China as among those economies facing premature deindustrialization. However, Rodrik (2016) notes that deindustrialization is more evident in terms of manufacturing employment share than in terms of value-added share (due to reliance on value-added measures at current prices rather than constant prices). Similarly, Felipe et al. (2019) find that output shares are poor performers relative to employment shares in tracing peak industrialization periods in economies. Considering these facts, we define deindustrialization in two ways - first, by considering the fall in both the employment share and the value-added share of manufacturing (conditions 1 and 2) and second by considering only the fall in the employment share of manufacturing (condition 1).

Next, we need to distinguish the deindustrialization phase as premature or not. The description of deindustrialization as premature implies that the economy is at lower income levels and is yet to exploit the possibilities of manufacturing-driven economic growth (Felipe et al. 2019; Rodrik

\footnotetext{
${ }^{4}$ Appendix Tables A1 and A2 provides the aggregation of activities into sectors based on the ISIC of all economic activities, Revision 4 (Rev. 4).
} 
2016). Hence, to identify the 'premature' element in economies, we specify threshold levels of income and share of manufacturing (in employment and value-added). These thresholds (conditions 3-5) imply that a deindustrialization phase is premature if the economy is at lower income levels and the manufacturing sector is yet to achieve dominant status in terms of both employment and value-added share.

The proposed method to detect premature deindustrialization consists of the following five conditions:

$$
\begin{aligned}
& \operatorname{Eman}_{t-n, t} \geq \operatorname{Eman}_{t, t+n} \\
& \operatorname{VAman}_{t-n, t} \geq \operatorname{VAman}_{t, t+n}
\end{aligned}
$$

$y_{t} \leq \$ 11,750$

$\operatorname{Eman}_{t} \leq 0.18$

$\operatorname{VAman}_{t} \leq 0.18$

where time period $t=1,2, \ldots, T$ and $T$ is the most recent period for which the data are available. $y_{t}$ is the GDP per capita (in 2015 constant US dollars) in the year $t$. Eman $\operatorname{Em}_{t-n, t}$ (or VAman $\operatorname{Am}_{t-n, t}$ ) represents the average share of manufacturing employment (or value-added) between year $t-n$ and $t$. Similarly, $\operatorname{Eman}_{t, t+n}$ (or $V A \operatorname{man}_{t, t+n}$ ) indicates an average manufacturing employment (or value-added) share between year $t$ and $t+n . V A m a n_{t}$ and $E m a n_{t}$ are the share of manufacturing value-added and employment in year $t$, respectively. We use manufacturing value-added share at constant prices (2015 US\$) to capture VAman. ${ }^{5}$ This study considers $n$ as seven years, following Eichengreen et al. (2012) and Hausmann et al., (2005). ${ }^{6}$ Felipe et al. (2019) also consider a sevenyear moving average of industrial employment and output to track industrialization in the economy.

Data on manufacturing value-added share and GDP per capita are from UNSD (2020). The data for manufacturing employment share are from ILOSTAT (2020). Our sample consists of 54 middle-income countries for the period 1992 to 2017. The sectoral employment data act as a major binding constraint for selecting the sample countries and time periods.

The first and second conditions trace the deindustrialization trend in economies in terms of employment and value-added share of manufacturing, respectively. The first (second) condition implies that if the seven-year average manufacturing employment (value-added) share in the current period $(t$ to $t+n)$ is lower than in the previous period $(t-n$ to $t$ ), the economy is experiencing a deindustrialisation phase in period $t$ to $t+n .^{7}$ Hence, for deindustrialization to

\footnotetext{
${ }^{5}$ Rodrik (2016) specifies that value-added share at constant prices is a better measure of deindustrialization than valueadded at current prices.

${ }^{6}$ While Hausmann et al. (2005) use $n$ equal to seven year to capture growth acceleration periods, Eichengreen et al. (2012) set $n$ as seven years to identify economies facing growth slow-down episodes. Since structural transformation is associated with growth episodes and is a long-run phenomenon, we assume that $n$ equals seven years to capture a deindustrialization period.

${ }^{7}$ Eichengreen et al. (2012) specify similar conditions in terms of growth rate for identifying growth slow-downs in the economy.
} 
occur, the current period's average manufacturing share (in employment or value-added) should be lower than that of the previous period.

The third condition states that $y_{t}$ (GDP per capita in 2015 constant US\$) is less than $\$ 11,750$. According to Felipe et al. (2017), this is the upper threshold level of the classification of an economy as a middle-income country. If an economy achieves an income higher than this threshold, then that economy has reached the high-income category. Hence, if deindustrialization occurs below this income level, it signals the 'premature' element in the shrinking manufacturing share.

The fourth and fifth conditions specify that the economy in the year $t$ should not have employment and value-added shares of manufacturing greater than 18 per cent. Felipe et al. (2019) show that the probability of graduating into rich-country status increases if an economy has an manufacturing employment share of above 18 per cent. The authors also highlight that if an economy fails to reach this threshold level in manufacturing share (especially in employment), this signals premature deindustrialization. We adopt this 18 per cent threshold in both the employment and the value-added share of manufacturing to represent economies experiencing premature deindustrialisation. ${ }^{8}$ This threshold implies that the manufacturing sector is not the dominant sector in the economy.

If all the five conditions are satisfied, we consider an economy to be experiencing premature deindustrialization. This method identifies that 32 economies have faced a premature deindustrialization phase at various periods. We also use an alternative definition to identify premature deindustrialization. In this alternative definition, we detect an deindustrialization phase by excluding condition 2 (i.e., excluding a fall in the manufacturing value-added share) and considering only condition 1 (the fall in manufacturing employment share). Then, countries such as Albania, India, Iran, and Turkey are added to the list of economies facing premature deindustrialization. Appendix Table A4 provides details of the premature deindustrialization cases identified through both approaches.

\section{Structural transformation and income inequality: trends and patterns in middle- income countries}

In this section, we explore trends in income inequality and how these are associated with the premature deindustrialization pattern in middle-income economies. Figure 1 reveals that countries with premature deindustrialization have faced high levels of inequality over the past two decades. The net income per capita Gini (Gini based on income after taxes and transfers) is at or above 40 per cent in the majority of these economies. Among them, South Africa, Namibia, and Botswana have exceptionally high and persisting inequality levels. Even though some economies, such as Algeria, Bolivia, Brazil, Ecuador, and Peru, depict a falling trend, the income inequality level is still high in these economies. Another interesting fact is that these economies are mainly in Africa, Latin America, and Asia, where the level of income inequality continues to be very high compared with developed countries.

\footnotetext{
${ }^{8}$ Felipe et al. (2019) also consider a threshold of $18 \%$ for employment and output shares to define rich-country status. The authors find that having an employment share above $18 \%$ matters in defining a country as a rich country, whereas this is not the case for the value-added share.
} 
Figure 1 depicts that in countries with premature deindustrialization, both the employment and the value-added share of manufacturing have experienced a continuous fall for the past two decades. In contrast, if we observe the sectoral labour productivity of the sample of 54 middleincome countries, except for seven economies, all others have industry as the highest-productivity sector in the economy (See Appendix Table A3). Furthermore, in none of these 54 economies does industry emerge as the dominant employment provider. In most cases, it is services that contributes the largest share in total employment. Thus, middle-income economies have mostly experienced services-driven structural transformation along with a deindustrialization trend.

Figure 2 plots the path of income inequality with a rise in service employment share in countries facing premature deindustrialization (left-hand graph). There is a negative relationship between inequality and the services employment share. The right-hand graph in Figure 2 reveals that this relationship changes when we consider the different subsectors of the services sector-namely, business market services, non-business market services, and non-market services. An increase in both business market services and non-market services leads to a fall in income inequality, whereas an increase in non-business market services results in a hump-shaped relationship with income inequality. 
Figure 1: The trend in the share of manufacturing employment, manufacturing value-added, and net Gini in middle-income countries facing premature deindustrialization

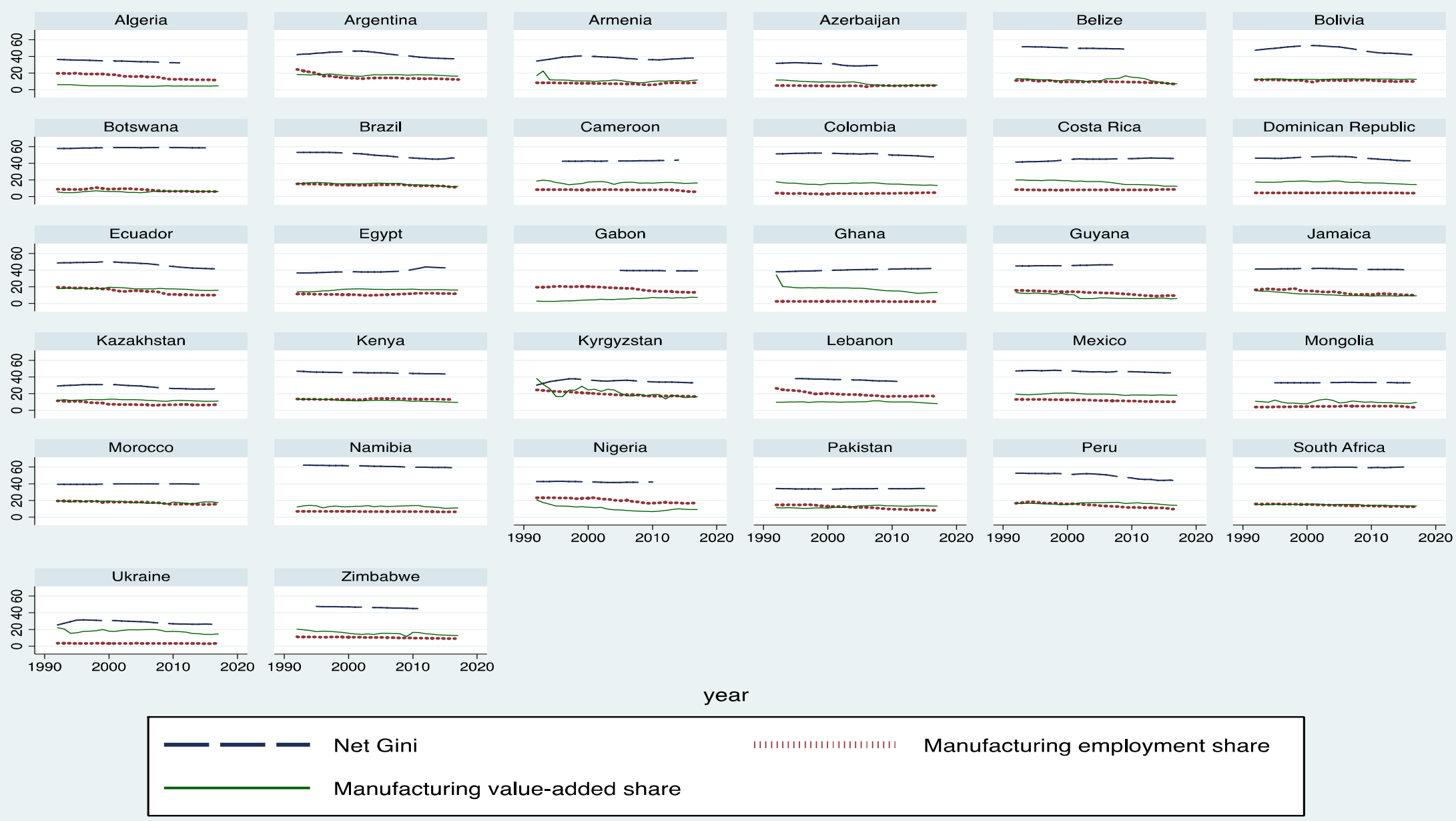

Source: authors' illustration based on ILOSTAT (2020); UNU-WIDER (2020); UNSD (2020). 
Figure 2: Relationship between income inequality and services employment share (left-hand graph) and services subsectors (right-hand graph) in countries facing premature deindustrialization

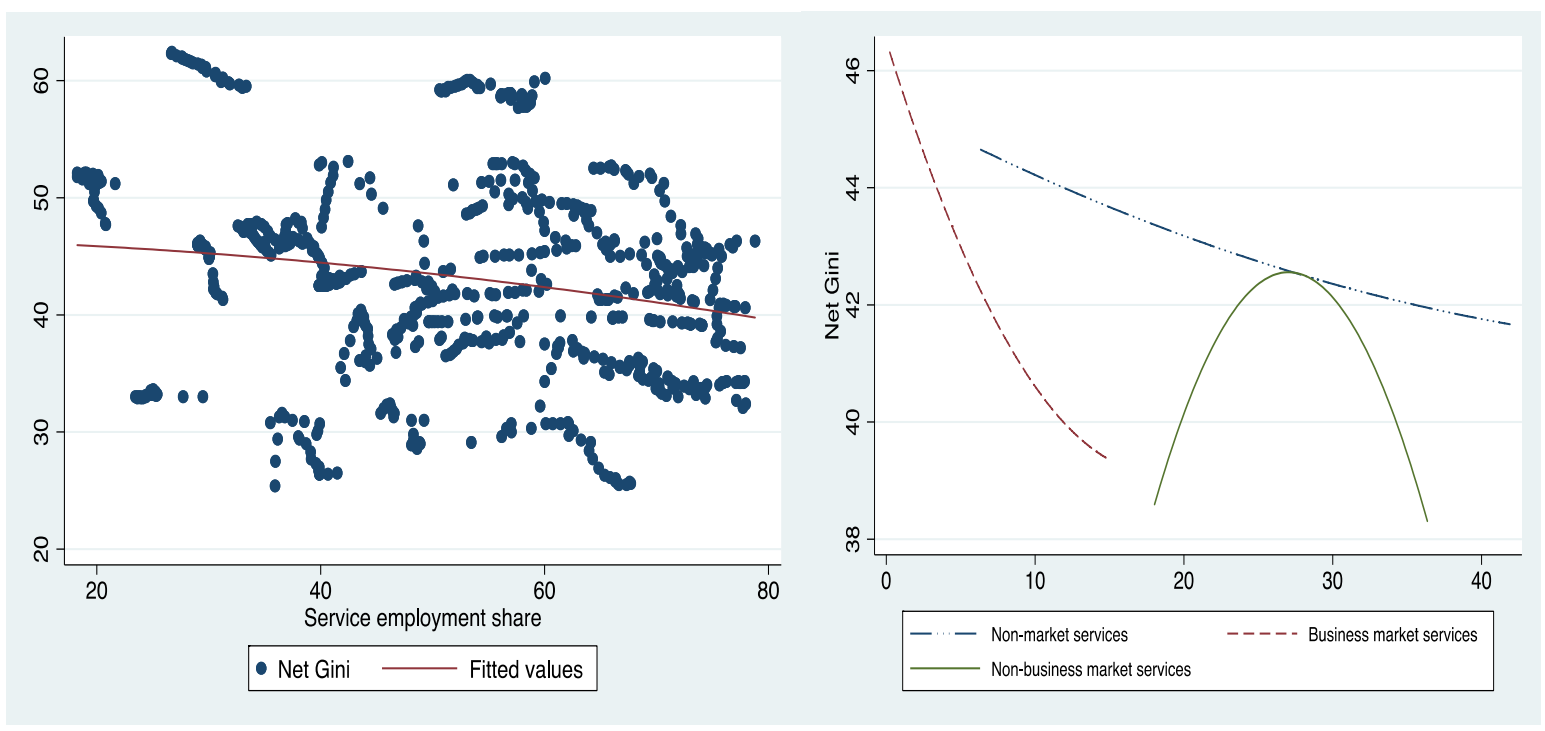

Note: in the right-hand graph, the service subsectors include business market services, non-business market services, and non-market services.

Source: authors' illustration based on ILOSTAT (2020); UNU-WIDER (2020).

\section{The relationship between premature deindustrialization and income inequality}

\subsection{Empirical strategy}

This paper primarily examines the implications of an early deindustrialization trend (coupled with a service-driven labour transition) for the income inequality levels of middle-income countries. To capture this relationship, we estimate the marginal effect on net Gini (net income per capita Gini) when service sector employment increases in the presence of premature deindustrialization (Equation 6).

$$
\begin{gathered}
\text { Gini }_{i t}=\beta_{1} \text { Service }_{i t}+\beta_{2} \text { Service }_{i t}^{2}+\beta_{3} \text { Agriculture }_{i t}+\beta_{4} P D I_{i t}+\beta_{5} P D I * \text { Services }_{i t} \\
+\beta_{6} P D I * \text { Services }_{i t}^{2}+\beta_{7} P D I * \text { Agriculture }_{i t}+\gamma_{X} X_{i t}+\sigma_{t}+\mu_{i}+e_{i t}
\end{gathered}
$$

where Service and Agriculture represent the employment share of these sectors in total employment. PDI denotes the dummy variable, which takes the value 1 for those years for which we detect a premature deindustrialization pattern in the economy. The main explanatory variables are the dummy (PDI) interaction terms with employment shares of services. To estimate the differential effects of the service subsectors on income inequality, in the empirical estimation we replace Service in Equation 6 with these subsectors. In this case, the main variables of interest are the interaction terms of premature deindustrialization $(P D I)$ and the employment share of service subsectors-namely, business market services, non-business market services, and nonmarket services. 
Gini is the dependent variable to capture the income inequality level in an economy. Following Baymul and Sen (2020), we consider the net Gini coefficient as the dependent variable (based on income after taxes and transfers). The variable $X$ represents the set of control variables, which includes GDP per capita, trade openness, government capital expenditure, population growth rate, and educational attainment. We use panel fixed-effects (FE), and bootstrap-corrected dynamic fixed-effects (BCFE) models to analyse the influence of deindustrialization on income inequality.

\subsection{Data}

The paper makes use of annual data spanning the period 1992-2017 across 54 middle-income countries. The availability of sectoral employment data constrains the selection of the sample period and countries. The sample includes middle-income countries from different regions of the world, including Asia, Latin America and the Caribbean (LAC), Sub-Saharan Africa (SSA), and Europe. In most of these economies, the services sector holds the largest share of employment, whereas industry has the largest share in terms of productivity (see Table A3 in the Appendix).

This study depends upon four primary sources for data assimilation—namely, WIID, ILO, UNSD, and WDI. To capture income inequality, we consider net Gini (net income per capita Gini coefficient) from WIID, Revision 4. The data for sectoral employment shares are from the database of the ILO. The ILO employment dataset consists of subsectoral employment data based on the fourth revision of the ISIC of all economic activities (ISIC Rev. 4). However, these data are available mostly from 1992 to 2017, which acts as a binding constraint for our sample selection. Data on manufacturing value-added share and GDP per capita are from UNSD (2020). The data source for control variables-trade openness, government final consumption expenditure, the annual growth rate of the population, and educational attainment—is World Bank (2020).

We employ an unbalanced panel dataset for empirical estimation. Table 1 reports the key summary statistics of variables used in the empirical analysis. The minimum value for net Gini is 23 per cent and the maximum is 62.4 percent, while the mean is 41.52 per cent. These values indicate the presence of a high level of income inequality among the countries in our sample. The minimum agriculture employment share is below 1 per cent, and the maximum is at 85 per cent. The maximum and minimum values of manufacturing employment are 30 and 0.4 per cent, respectively. In contrast, the maximum employment share of the services sector is around 85 per cent, the minimum share 12 per cent. The difference in the range of employment share in these sectors signals that the services sector is the dominant employment provider in our sample economies (see also Appendix Table A3). For instance, while the mean share of services employment is around 49 per cent, that of agriculture is only about 31 per cent and that of manufacturing 11 per cent. Within the services sector, if we compare the mean values, market services have a higher share in employment compared with non-market services. Within market services, non-business market services have an average contribution of 22 per cent of total employment, whereas the average share of business market services is only around 5 per cent. Thus, non-business market services such as trade, transport, food, and accommodation are the dominant employment providers in our sample relative to other service activities. 
Table 1: Summary statistics

\begin{tabular}{|c|c|c|c|c|c|}
\hline Variable & Obs. & Mean & Std Dev. & Min. & Max. \\
\hline Net Gini & 1,227 & 41.522 & 7.786 & 23 & 62.4 \\
\hline EMAN & 1,383 & 11.434 & 6.139 & 0.446 & 30.134 \\
\hline ESRV & 1,384 & 49.195 & 18.098 & 12.644 & 85.027 \\
\hline EAGR & 1,384 & 31.526 & 23.958 & 0.059 & 85.651 \\
\hline Emkt_srv & 1,383 & 27.983 & 9.442 & 9.417 & 45.58 \\
\hline Enonmkt_srv & 1,383 & 21.195 & 11.22 & 2.602 & 70.632 \\
\hline Ebus_srv & 1,383 & 5.021 & 4.172 & 0.158 & 18.784 \\
\hline Enonbus_srv & 1,383 & 22.962 & 6.341 & 9.093 & 36.358 \\
\hline PDI & 1,404 & 0.117 & 0.321 & 0 & 1 \\
\hline PDI_SRV & 1,383 & 6.467 & 18.249 & 0 & 78.797 \\
\hline PDI_AGR & 1,383 & 3 & 10.004 & 0 & 73.863 \\
\hline PDI_mktsrv & 1,383 & 3.552 & 10.144 & 0 & 44.595 \\
\hline PDI_nonmktsrv & 1,383 & 2.915 & 8.358 & 0 & 40.314 \\
\hline PDI_bus_srv & 1,383 & 0.692 & 2.345 & 0 & 14.989 \\
\hline PDI_nonbus_srv & 1,383 & 2.86 & 8.046 & 0 & 35.975 \\
\hline GDP_pc & 1,350 & 8.008 & 0.77 & 6.061 & 9.551 \\
\hline TROP & 1,404 & 76.5 & 36.835 & 14.731 & 274.973 \\
\hline GOV & 1,403 & 13.836 & 4.692 & 0.911 & 30.14 \\
\hline PPL & 1,404 & 1.477 & 1.129 & -2.39 & 6.568 \\
\hline Education & 1,300 & 7.6 & 18.545 & 0 & 96.308 \\
\hline
\end{tabular}

Note: Net Gini is the net income per capita Gini after taxes and transfers. EMAN, ESRV, EAGR, Emkt_srv, Enonmkt_srv, Ebus_srv, and Enonbus_srv are the employment shares of manufacturing, services, agriculture, market services, non-market services, business market services, and non-business market services in total employment, respectively. PDI represents the dummy, which takes the value 1 if the country is experiencing premature deindustrialization, zero otherwise, following the criteria outlined in Section 2. When this dummy variable interacts with employment share of services, agriculture, market services, non-market services, business market services, and non-business market services, we obtain the variables PDI_SRV, PDI_AGR, PDI_mktsrv, PDI_nonmktsrv, PDI_bus_srv, and PDI_nonbus_srv, respectively. GDP_pc represents the variable GDP per capita in log form. TROP indicates the variable trade openness as a percentage of GDP. GOV is the annual percentage growth rate of government final consumption expenditure. PPL is the annual population growth rate. Education is the percentage of the population that has at least completed upper secondary education.

Source: authors' construction based on ILOSTAT (2020); UNSD (2020); UNU-WIDER (2020); World Bank (2020).

\section{$5 \quad$ Results and discussion}

This section presents the regression results examining the implications of premature deindustrialization for income inequality. In Table 2, Column I reports the panel FE estimation results of Equation 6. Column II presents regression results when we substitute employment in services with its components - employment share of market services and non-market servicesin Equation 6. Column III is similar to Column II, except for the fact that in Column III we replace market services with its components-employment share of business market services and non-business market services. The Hausman specification test supports the FE model over the random-effects model; hence, in Table 2 we report panel FE estimation results in Columns I-III.

The findings in Table 2 indicate that in middle-income countries, a services-driven structural transformation initially results in an increase in inequality and then in a decreases. The linear and quadratic terms of service employment share (in Column I) are significant at the 1 per cent level and depict an inverted-U-shaped relationship with net Gini. Baymul and Sen (2020) document a 
similar relationship between service employment share and income inequality. In Column II, the employment share of market services significantly (at the 1 per cent level) affects income inequality, with the linear and square terms depicting positive and negative relationships. Similarly, the employment share of both non-business market services and business market services (the components of market services) show an inverted-U-shaped relationship with inequality (Column III). The linear and quadratic coefficients of business market services employment share are significant at the 5 per cent level, and those of non-business market services are significant at the 1 per cent level. However, non-market services' employment share has no significant influence on income inequality (in either Column II or Column III). Thus in the middle-income economies the services sector has an inverted-U-shaped relationship with income inequality, and this relationship results primarily from an increase in the employment share of market services (both business and non-business market services) rather than non-market services. Concerning agricultural employment, we find that its coefficient is positive and significantly (at the 1 per cent level) affects income inequality. This result indicates that a labour shift away from agriculture through structural transformation is beneficial for economies in reducing income inequality.

Table 2: Regression results

\begin{tabular}{|c|c|c|c|c|c|}
\hline & (I) & (II) & (III) & (IV) & (IV) \\
\hline & FE & FE & FE & BCFE & BCFE \\
\hline Dep. Var. & Net Gini & Net Gini & Net Gini & Net Gini & Net Gini \\
\hline \multirow[t]{2}{*}{ L. Net Gini } & & & & $1.034^{\star \star \star}$ & $1.024^{\star \star \star}$ \\
\hline & & & & $(0.012)$ & (0.014) \\
\hline \multirow[t]{2}{*}{ ESRV } & $0.522^{\star \star \star}$ & & & & \\
\hline & $(0.111)$ & & & & \\
\hline \multirow[t]{2}{*}{ ESRV2 } & $-0.003^{\star \star \star}$ & & & & \\
\hline & $(0.001)$ & & & & \\
\hline \multirow[t]{2}{*}{ Emkt_srv } & & $0.5^{\star \star \star}$ & & -0.044 & \\
\hline & & (0.118) & & $(0.055)$ & \\
\hline \multirow[t]{2}{*}{ Emkt_srv2 } & & $-0.006^{\star \star \star}$ & & 0.001 & \\
\hline & & (0.001) & & $(0.0007)$ & \\
\hline \multirow[t]{2}{*}{ Ebus_srv } & & & $0.305^{\star \star}$ & & -0.03 \\
\hline & & & $(0.151)$ & & $(0.078)$ \\
\hline \multirow[t]{2}{*}{ Ebus_srv2 } & & & $-0.016^{\star \star}$ & & 0.003 \\
\hline & & & $(0.007)$ & & $(0.003)$ \\
\hline \multirow[t]{2}{*}{ Enonbus_srv } & & & $0.624^{\star \star \star}$ & & -0.007 \\
\hline & & & $(0.159)$ & & $(0.095)$ \\
\hline \multirow[t]{2}{*}{ Enonbus_srv2 } & & & $-0.01^{\star \star \star}$ & & 0.0001 \\
\hline & & & $(0.003)$ & & $(0.001)$ \\
\hline \multirow[t]{2}{*}{ Enonmkt_srv } & & 0.145 & 0.128 & -0.021 & -0.025 \\
\hline & & $(0.089)$ & $(0.091)$ & $(0.046)$ & $(0.038)$ \\
\hline Enonmkt_srv2 & & -0.001 & -0.0004 & 0.0001 & 0.0001 \\
\hline
\end{tabular}




\begin{tabular}{|c|c|c|c|c|c|}
\hline & & $(0.001)$ & $(0.001)$ & $(0.001)$ & $(0.0004)$ \\
\hline \multirow[t]{2}{*}{ EAGR } & $0.178^{\star * *}$ & $0.115^{\star \star \star}$ & $0.115^{\star \star \star}$ & -0.024 & -0.025 \\
\hline & $(0.043)$ & $(0.037)$ & $(0.036)$ & $(0.021)$ & $(0.016)$ \\
\hline \multirow[t]{2}{*}{ PDI } & 0.274 & 0.323 & 0.323 & -0.023 & -0.03 \\
\hline & $(0.229)$ & $(0.231)$ & $(0.231)$ & $(0.053)$ & $(0.042)$ \\
\hline \multirow[t]{2}{*}{ PDI_SRV } & $-0.089 \star \star$ & & & & \\
\hline & $(0.042)$ & & & & \\
\hline \multirow[t]{2}{*}{ PDI_SRV2 } & $0.001^{* *}$ & & & & \\
\hline & $(0.001)$ & & & & \\
\hline \multirow[t]{2}{*}{ PDI_mktsrv } & & 0.149 & & $0.108^{\star \star}$ & \\
\hline & & $(0.116)$ & & $(0.042)$ & \\
\hline \multirow[t]{2}{*}{ PDI_mktsrv2 } & & -0.001 & & $-0.001^{\star \star}$ & \\
\hline & & $(0.002)$ & & $(0.001)$ & \\
\hline \multirow[t]{2}{*}{ PDI_bus_srv } & & & 0.283 & & 0.085 \\
\hline & & & $(0.271)$ & & $(0.087)$ \\
\hline \multirow[t]{2}{*}{ PDI_bus_srv2 } & & & -0.016 & & -0.005 \\
\hline & & & $(0.014)$ & & $(0.004)$ \\
\hline \multirow[t]{2}{*}{ PDI_nonbus_srv } & & & 0.085 & & $0.136^{* *}$ \\
\hline & & & $(0.199)$ & & $(0.06)$ \\
\hline \multirow[t]{2}{*}{ PDI_nonbus_srv2 } & & & -0.001 & & $-0.002^{* *}$ \\
\hline & & & $(0.004)$ & & $(0.001)$ \\
\hline \multirow[t]{2}{*}{ PDI_nonmktsrv } & & $-0.288^{\star \star \star}$ & $-0.302^{\star \star \star}$ & $-0.12^{\star \star \star}$ & -0.129 *** \\
\hline & & $(0.1)$ & $(0.109)$ & $(0.032)$ & $(0.034)$ \\
\hline \multirow[t]{2}{*}{ PDI_nonmktsrv2 } & & $0.005^{\star \star \star}$ & $0.006^{\star \star *}$ & $0.002^{\star \star \star}$ & $0.002^{\star \star *}$ \\
\hline & & $(0.002)$ & $(0.002)$ & $(0.001)$ & $(0.001)$ \\
\hline \multirow[t]{2}{*}{ PDI_AGR } & $0.027^{*}$ & 0.006 & 0.014 & -0.007 & -0.008 \\
\hline & $(0.016)$ & $(0.018)$ & $(0.024)$ & $(0.005)$ & $(0.007)$ \\
\hline \multirow{2}{*}{ GDP_pc } & $3.202^{\star \star \star}$ & $3.264^{\star \star \star}$ & $3.22^{\star \star \star}$ & 0.016 & 0.039 \\
\hline & $(0.373)$ & $(0.375)$ & $(0.381)$ & $(0.247)$ & $(0.325)$ \\
\hline \multirow[t]{2}{*}{ TROP } & $-0.006^{\star}$ & -0.005 & -0.006 & -0.001 & -0.001 \\
\hline & $(0.003)$ & $(0.003)$ & $(0.003)$ & $(0.001)$ & $(0.002)$ \\
\hline \multirow[t]{2}{*}{ GOV } & -0.004 & -0.003 & -0.014 & 0.001 & 0.004 \\
\hline & $(0.023)$ & $(0.023)$ & $(0.023)$ & $(0.007)$ & $(0.007)$ \\
\hline \multirow[t]{2}{*}{ PPL } & $-0.224^{\star \star}$ & $-0.252^{\star \star}$ & $-0.271^{\star \star}$ & 0.004 & 0.006 \\
\hline & $(0.108)$ & $(0.11)$ & $(0.111)$ & $(0.045)$ & $(0.044)$ \\
\hline Education & $-0.01^{\star \star *}$ & 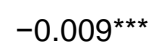 & $-0.008^{\star *}$ & 0.0003 & 0.0001 \\
\hline
\end{tabular}




\begin{tabular}{lrrrrr}
\hline & $(0.003)$ & $(0.003)$ & $(0.003)$ & $(0.001)$ & $(0.001)$ \\
Year dummy & Yes & Yes & Yes & Yes & Yes \\
Constant & -4.18 & 1.165 & 1.115 & & 1,045 \\
Numbers of obs. & 1,123 & 1,123 & 1,123 & 1,045 & 1,27 \\
R-squared & 0.25 & 0.27 & 0.27 & \\
\hline
\end{tabular}

Note: this table reports the relationship between structural transformation and income inequality. All explanatory variables except for the dummy variable, PDI, are in their one-period lag terms. ${ }^{* *}$, ${ }^{* *}$, and * imply $p<0.01$, $p<0.05$, and $p<0.1$, respectively. Standard errors are in parentheses. The employment shares of services and its subsectors in total employment are in both linear and quadratic terms.

Source: authors' construction based on own results.

We now consider the influence of premature deindustrialization on inequality, which is the primary focus of this paper. With an increase in services employment in premature deindustrialization cases, inequality reduces in the initial stage and increases at higher levels of services employment share (Column I). Though this finding contradicts our earlier results (without considering premature deindustrialization), the subsectoral analysis implies that this contradiction primarily arises from the influence of non-market services. When economies experience premature deindustrialization, the employment shares of market services (Column II) and its componentsboth business and non-business services (Column III) — do not significantly affect the income inequality level. However, in premature deindustrialization episodes, the coefficient of non-market services is negative and significant at the 1 per cent level (in both Columns II and III). The coefficient of agriculture employment in deindustrialization cases is positive and significant at the 10 per cent level in Column I and not significant in Columns II and III). Concerning the control variables in Columns I to III, GDP per capita has a positive and significant effect, while population growth rate and education have a negative and significant effect, on net Gini. Both trade openness and government expenditure have no discernible impact on the level of inequality.

\subsection{Robustness check}

The literature on income inequality often reports that inequality has dynamic effects, i.e. the level of past income inequality affects the current state of inequality (Calderón and Chong 2001; Chong 2004). We capture this dynamic relationship by adding lagged dependent variables to the individual-effect panel model specification. Thus, to check the robustness of our results, we are using iterative bootstrap-based bias correction for the FE estimator in dynamic panels, based on Everaert and Pozzi (2007).

From BCFE estimation (Columns IV and V in Table 2), we can confirm that with premature deindustrialization, an increase in non-market services reduces income inequality initially and increases it at a higher level of employment share. The coefficients of both the linear and quadratic terms of non-market services are significant at the 1 per cent level. In contrast, market services have a hump-shaped relationship with inequality under premature deindustrialization (Column IV). The linear coefficient of market services is positive and significant at the 5 per cent level, and the coefficient of the square term is negative with a 5 per cent significance level. When we consider the components of market services (Column V), the coefficient of business services' employment share has no significant effect on net Gini. However, as the employment share of non-business market services rises, the level of income inequality follows an inverted-U-shaped relationship. The coefficient of the linear and quadratic terms of non-business market services are positive and negative (at the 5 per cent level of significance), respectively. 
We also check whether our results (as in Table 2) hold when we use the alternative definition for premature deindustrialization. In this alternative definition, we use only the trend in manufacturing employment share (and not value-added share, i.e. excluding condition 2 as described in Section 2) while identifying deindustrialization phases. ${ }^{9}$ In this case, we apply both the FE and BCFE models to estimate the inequality-structural transformation relationship. Table 3 provides the empirical results. In this method, the dummy variable indicating premature deindustrialization significantly (at 1 per cent level) and positively affects income inequality (Columns I-III). This result emphasizes that a premature deindustrialization pattern can increase income inequality in middleincome economies. The findings are consistent with the earlier results (in Table 2), with the employment share of non-market services having a U-shaped relationship and that of market services having a positive linear relationship with income inequality.

Table 3: Regression results with alternative identification of premature deindustrialization

\begin{tabular}{|c|c|c|c|c|c|}
\hline & (I) & (II) & (III) & (IV) & (IV) \\
\hline & FE & FE & FE & BCFE & BCFE \\
\hline Dep. Var. & Net Gini & Net Gini & Net Gini & Net Gini & Net Gini \\
\hline \multirow{2}{*}{ L. Net Gini } & & & & $1.028^{\star \star \star}$ & $1.028^{\star \star \star}$ \\
\hline & & & & $(0.013)$ & (0.013) \\
\hline \multirow[t]{2}{*}{ ESRV } & $0.535^{\star \star \star}$ & & & & \\
\hline & $(0.111)$ & & & & \\
\hline \multirow[t]{2}{*}{ ESRV2 } & $-0.003^{\star \star \star}$ & & & & \\
\hline & $(0.001)$ & & & & \\
\hline \multirow[t]{2}{*}{ Emkt_srv } & & $0.54^{\star \star \star}$ & & -0.041 & \\
\hline & & $(0.117)$ & & $(0.055)$ & \\
\hline \multirow[t]{2}{*}{ Emkt_srv2 } & & $-0.007^{\star \star \star}$ & & 0.001 & \\
\hline & & $(0.001)$ & & $(0.0007)$ & \\
\hline \multirow[t]{2}{*}{ Ebus_srv } & & & $0.324^{\star \star}$ & & -0.014 \\
\hline & & & $(0.155)$ & & $(0.066)$ \\
\hline \multirow[t]{2}{*}{ Ebus_srv2 } & & & $-0.168^{\star \star}$ & & 0.002 \\
\hline & & & $(0.007)$ & & $(0.003)$ \\
\hline \multirow[t]{2}{*}{ Enonbus_srv } & & & $0.668^{\star \star \star}$ & & -0.013 \\
\hline & & & $(0.161)$ & & $(0.077)$ \\
\hline \multirow[t]{2}{*}{ Enonbus_srv2 } & & & $-0.011^{\star \star \star}$ & & 0.0002 \\
\hline & & & $(0.003)$ & & (0.001) \\
\hline \multirow[t]{2}{*}{ Enonmkt_srv } & & $0.162^{*}$ & 0.132 & -0.02 & -0.023 \\
\hline & & $(0.088)$ & $(0.09)$ & $(0.041)$ & $(0.05)$ \\
\hline Enonmkt_srv2 & & -0.001 & -0.0005 & -0.0001 & 0.0001 \\
\hline
\end{tabular}

\footnotetext{
${ }^{9}$ In this alternative definition for premature deindustrialization, we use conditions 1,3 , 4, and 5 as described in Section 2 .
} 


\begin{tabular}{|c|c|c|c|c|c|}
\hline & & $(0.001)$ & $(0.001)$ & $(0.001)$ & $(0.001)$ \\
\hline \multirow[t]{2}{*}{ EAGR } & $0.182^{\star \star \star}$ & $0.124^{\star \star \star}$ & $0.12^{\star \star \star}$ & -0.023 & -0.023 \\
\hline & $(0.043)$ & $(0.036)$ & $(0.036)$ & $(0.02)$ & $(0.018)$ \\
\hline \multirow[t]{2}{*}{ PDI } & $0.471^{* \star}$ & $0.568^{\star \star \star}$ & $0.571^{\star \star \star}$ & 0.031 & 0.026 \\
\hline & $(0.214)$ & $(0.214)$ & $(0.214)$ & $(0.038)$ & $(0.045)$ \\
\hline \multirow[t]{2}{*}{ PDI_SRV } & $-0.067^{\star}$ & & & & \\
\hline & $(0.036)$ & & & & \\
\hline \multirow[t]{2}{*}{ PDI_SRV2 } & $0.001^{*}$ & & & & \\
\hline & $(0.0005)$ & & & & \\
\hline \multirow[t]{2}{*}{ PDI_mktsrv } & & $0.174^{\star}$ & & 0.062 & \\
\hline & & $(0.093)$ & & $(0.039)$ & \\
\hline \multirow[t]{2}{*}{ PDI_mktsrv2 } & & -0.002 & & -0.001 & \\
\hline & & $(0.002)$ & & $(0.001)$ & \\
\hline \multirow[t]{2}{*}{ PDI_bus_srv } & & & 0.288 & & 0.094 \\
\hline & & & $(0.189)$ & & $(0.07)$ \\
\hline \multirow[t]{2}{*}{ PDI_bus_srv2 } & & & -0.015 & & -0.005 \\
\hline & & & $(0.01)$ & & (0.004) \\
\hline \multirow[t]{2}{*}{ PDI_nonbus_srv } & & & 0.105 & & 0.087 \\
\hline & & & $(0.147)$ & & $(0.053)$ \\
\hline \multirow[t]{2}{*}{ PDI_nonbus_srv2 } & & & -0.001 & & -0.0018 \\
\hline & & & $(0.003)$ & & (0.001) \\
\hline \multirow[t]{2}{*}{ PDI_nonmktsrv } & & $-0.314^{\star \star \star}$ & $-0.336^{\star \star \star}$ & $-0.095^{\star \star \star}$ & $-0.111^{\star \star *}$ \\
\hline & & $(0.075)$ & $(0.084)$ & $(0.035)$ & $(0.038)$ \\
\hline \multirow[t]{2}{*}{ PDI_nonmktsrv2 } & & $0.005^{\star \star \star}$ & $0.006^{\star \star \star}$ & $0.002^{\star \star \star}$ & $0.002^{\star \star *}$ \\
\hline & & $(0.001)$ & $(0.001)$ & $(0.001)$ & $(0.001)$ \\
\hline \multirow[t]{2}{*}{ PDI_AGR } & $0.031^{\star *}$ & 0.010 & 0.022 & -0.002 & -0.003 \\
\hline & $(0.014)$ & $(0.016)$ & $(0.019)$ & $(0.005)$ & $(0.01)$ \\
\hline \multirow[t]{2}{*}{ GDP_pc } & $3.245^{\star \star \star}$ & $3.265^{\star \star \star}$ & $3.26^{\star \star \star}$ & -0.016 & 0.02 \\
\hline & $(0.372)$ & $(0.371)$ & $(0.382)$ & $(0.251)$ & $(0.31)$ \\
\hline \multirow[t]{2}{*}{ TROP } & -0.005 & -0.006 & $-0.006^{*}$ & -0.001 & -0.001 \\
\hline & $(0.003)$ & $(0.004)$ & $(0.003)$ & $(0.001)$ & $(0.002)$ \\
\hline \multirow[t]{2}{*}{ GOV } & 0.003 & -0.003 & -0.012 & 0.001 & 0.003 \\
\hline & $(0.023)$ & $(0.023)$ & $(0.023)$ & $(0.006)$ & $(0.005)$ \\
\hline \multirow[t]{2}{*}{ PPL } & $-0.223^{\star \star}$ & $-0.251^{\star \star}$ & $-0.281^{\star \star}$ & -0.001 & -0.004 \\
\hline & $(0.108)$ & $(0.11)$ & $(0.112)$ & $(0.052)$ & $(0.051)$ \\
\hline Education & $-0.01^{\star \star \star}$ & $-0.009^{\star \star \star}$ & $-0.007^{\star *}$ & 0.0003 & 0.0001 \\
\hline
\end{tabular}




\begin{tabular}{lrrrrr}
\hline & $(0.003)$ & $(0.003)$ & $(0.003)$ & $(0.001)$ & $(0.001)$ \\
Year dummy & Yes & Yes & Yes & Yes & Yes \\
Constant & -5.203 & 1.165 & 1.115 & & 1,045 \\
Numbers of obs. & 1,123 & 1,123 & 1,123 & 1,045 & \\
R-squared & 0.25 & 0.27 & 0.27 & & \\
\hline
\end{tabular}

Note: this table reports the relationship between income inequality and structural transformation when we consider an alternative identification method for premature deindustrialization. To identify premature deindustrialization, we exclude condition 2 and include conditions 1,3,4, and 5 as described in Section 2. Thus, we consider only trends in manufacturing employment share in this table to define the variable PDI. All explanatory variables except for the dummy variable, PDI, are in their one-period lag terms. Standard errors are in parentheses. ${ }^{* \star *}$, ${ }^{* *}$, and * imply $p<0.01, p<0.05$, and $p<0.1$, respectively.

Source: authors' construction based on own results.

To sum up, the empirical findings suggest that income inequality rises with premature deindustrialization if the displaced workers are absorbed into market services (especially with employment increase in non-business market services such as trade, transport, hotels, and accommodation activities). In contrast to this relationship, if the employment share of highproductivity non-market services increases, this helps in reducing income inequality when an economy faces premature deindustrialization.

\section{Conclusion}

Structural transformation (labour transition from one sector to another) is one of the central channels for economic development. Nevertheless, it often brings with it a trade-off between economic growth and income inequality, known as the 'developer's dilemma' (Sumner and London 2017). A recent study by Baymul and Sen (2020) shows that this dilemma (i.e. economic growth results in higher income inequality) occurs when the labour movement is services-driven rather than when it is manufacturing-driven. These findings imply that besides manufacturing being an engine of growth, developing economies can rely on it to resolve income inequality issues.

Nevertheless, middle-income economies are deviating from the traditional path of industry-driven structural transformation. After some initial industrialization experience, most of these economies are turning towards the services sector, leading to early deindustrialization. Developed economies experienced the deindustrialization phase (a fall in manufacturing employment or output) after they achieved higher per capita income. In contrast, in developing economies, the contraction in the manufacturing employment (or output) share is occurring at lower levels of income, known as 'premature deindustrialization'. Given this background, we empirically examine the implications of early deindustrialization for income inequality as the services employment share increases in countries that face premature deindustrialization.

To identify economies which are facing premature deindustrialization, we propose a novel method which consists of five conditions. Through this method, we attempt to solve some of the ambiguities that exist in defining premature deindustrialization cases. The first and second conditions detect a deindustrialization trend in economies if there is a fall in the manufacturing employment and value-added shares, respectively. The last three conditions check whether a deindustrialization phase is 'premature' by providing thresholds in terms of income and the shares of manufacturing employment and value-added. Among the 54 middle-income countries, 32 satisfy these criteria. These economies are mainly in the LAC, SSA, and South Asian regions. 
The empirical results suggest that for middle-income countries in general, the inequality level rises in the initial stage of structural transformation with an increase in services sector employment. However, in the presence of premature deindustrialization, this relationship depends on which services subsector acts as the dominant player in labour absorption. If the premature deindustrialization trend causes the displaced manufacturing sector workers to be absorbed into non-business market services, income inequality will rise. In contrast to this relationship, if nonmarket services are the dominant employment provider, this helps to reduce income inequality in economies facing premature deindustrialization.

For developing economies facing premature deindustrialization, reviving the industrial sector might be an uphill task. Furthermore, Newfarmer and Page (2018) suggest that in the case of Africa, structural transformation relies on a new set of activities known as industries without smokestacks' (high-value agriculture, horticulture, tourism, business services, and other tradeable services). The advantage is that, as in the manufacturing sector, these activities have both high productivity and high employment generation capacity. To resolve the developer's dilemma, the challenge before policy-makers is to enhance the scope of services activities in generating more productive employment opportunities for both skilled and unskilled labourers.

\section{References}

Baymul, C., and K. Sen (2020). 'Was Kuznets Right? New Evidence on the Relationship between Structural Transformation and Inequality'. The Journal of Development Studies, 56(1): 1-20. https://doi.org/ 10.1080/00220388.2019.1702161

Calderón, C., and A. Chong (2001). 'External Sector and Income Inequality in Interdependent Economies using a Dynamic Panel Data Approach'. Economics Letters, 71(2): 225-31. https://doi.org/ 10.1016/S0165-1765(01)00374-3

Chong, A. (2004). 'Inequality, Democracy, and Persistence: Is There a Political Kuznets Curve?' Economics \& Politics, 16(2): 189-212. https://doi.org/10.1111/j.1468-0343.2004.00137.x

Dasgupta, S., and A. Singh (2006). 'Manufacturing, Services and Premature Deindustrialization in Developing Countries: A Kaldorian Analysis'. WIDER Working Paper 2006/49. Helsinki: UNUWIDER

Eichengreen, B., D. Park, and K. Shin (2012). 'When Fast-Growing Economies Slow Down: International Evidence and Implications for China'. Asian Economic Papers, 11(1): 42-87. https://doi.org/ 10.1162/ASEP_a_00118

Everaert, G., and L. Pozzi (2007). 'Bootstrap-Based Bias Correction for Dynamic Panels'. Journal of Economic Dynamics and Control, 31(4): 1160-84. https://doi.org/10.1016/j.jedc.2006.04.006

Felipe, J., U. Kumar, and R. Galope (2017). 'Middle-Income Transitions: Trap or Myth?' Journal of the Asia Pacific Economy, 22(3): 429-53. https://doi.org/10.1080/13547860.2016.1270253

Felipe, J., A. Mehta, and C. Rhee (2019). 'Manufacturing Matters, but It's the Jobs That Count'. Cambridge Journal of Economics, 43(1): 139-68. https://doi.org/10.1093/cje/bex086

Hausmann, R., L. Pritchett, and D. Rodrik (2005). 'Growth Accelerations'. Journal of Economic Growth, 10(1): 303-29. https:// doi.org/10.1007/s10887-005-4712-0

ILOSTAT (2020). 'Employment Statistics'. Geneva: ILO. Available at: https://ilostat.ilo.org/topics/ employment/\# (accessed 18 December 2020).

Jaumotte, F., S. Lall, and C. Papageorgiou (2013). 'Rising Income Inequality: Technology, or Trade and Financial Globalisation'. IMF Economic Review, 61(2): 271-309. https://doi.org/10.1057/imfer.2013.7 
Kuznets, S. (1955). 'Economic Growth and Income Inequality'. American Economic Review, 45(1): 1-28.

McMillan, M., D. Rodrik, and I. Verduczo-Gallo (2014). 'Globalisation, Structural Change and Productivity Growth, with an Update on Africa'. World Development, 63(1): 11-32. https://doi.org/10.1016/ j.worlddev.2013.10.012

Newfarmer, R., and J. Page (2018). 'Industries without Smokestacks: Industrialization in Africa Reconsidered'. WIDER Policy Brief 2/18. Helsinki: UNU-WIDER. https://doi.org/10.1093/ oso/9780198821885.001.0001

Palma, J.G. (2014). 'De-industrialisation, "Premature" De-industrialisation and the Dutch Disease'. Revista NECAT-Revista do Núcleo de Estudos de Economia Catarinense, 3(5): 7-23.

Rodrik, D. (2016). 'Premature Deindustrialisation'. Journal of Economic Growth, 21(1): 1-33. https://doi.org/ 10.1007/s10887-015-9122-3

Rowthorn, R., and R. Ramaswamy (1999). 'Growth, Trade and Deindustrialization'. IMF Staff Papers 46. Washington, DC: IMF.

Sarma, V., S. Paul, and G. Wan (2017). 'Structural Transformation, Growth, and Inequality: Evidence from Viet Nam’. ADBI Working Paper 681. Tokyo: Asian Development Bank Institute (ADBI).

Sumner, A., and A. London (2017). 'The Developer's Dilemma: The Inequality Dynamics of Structural Transformation and Inclusive Growth'. ESRC GPID Research Network Research Working Paper 1. London: ESRC (Economic and Social Research Council) GPID Global Poverty and Inequality Dynamics) Research Network.

Tregenna, F. (2009). 'Characterising Deindustrialization: An Analysis of Changes in Manufacturing Employment and Output Internationally'. Cambridge Journal of Economics, 33: 433-66. https:/ / doi.org/ $10.1093 / \mathrm{cje} / \mathrm{ben} 032$

Tregenna, F. (2013). 'Manufacturing Productivity, Deindustrialization and Reindustrialisation'. In A. Szirmai, W. Naudé, and L. Alcorta (eds), Pathways to Industrialization in the Twenty-First Century: New Challenges and Emerging Paradigms. Oxford: Oxford University Press.

UNCTAD (2003). Trade and Development Report 2003: Capital Accumulation, Growth and Structural Change. Geneva: UN Conference on Trade and Development (UNCTAD).

UNSD (2008). International Standard Industrial Classification of All Economic Activities: Revision 4. Series M No. 4/Rev. 4. New York: UNSD.

UNSD (2020). 'National Accounts: Analysis of Main Aggregates (AMA)'. New York: UNSD. Available at: https://unstats.un.org/unsd/snaama/Index (accessed 18 December 2020).

UNU-WIDER (2020). 'World Income Inequality Database-WIID', Version 4 (6 May 2020). Helsinki: UNU-WIDER. Available at: https://www.wider.unu.edu/database/wiid (accessed 18 December 2020).

World Bank (2020) 'World Development Indicators'. Washington, DC: World Bank. Available at: https://databank.worldbank.org/source/world-development-indicators (accessed 18 December 2020). 


\section{Appendix}

Table A1: Data aggregation by ISIC Rev. 4

\begin{tabular}{|c|c|}
\hline Section & Description \\
\hline A & Agriculture, forestry and fishing \\
\hline B & Mining and quarrying \\
\hline C & Manufacturing \\
\hline $\mathrm{D}$ & Electricity, gas, steam and air conditioning supply \\
\hline $\mathrm{E}$ & Water supply; sewerage, waste management and remediation activities \\
\hline $\mathrm{F}$ & Construction \\
\hline G & Wholesale and retail trade; repair of motor vehicles and motorcycles \\
\hline $\mathrm{H}$ & Transportation and storage \\
\hline I & Accommodation and food service activities \\
\hline $\mathrm{J}$ & Information and communication \\
\hline $\mathrm{K}$ & Financial and insurance activities \\
\hline $\mathrm{L}$ & Real estate activities \\
\hline M & Professional, scientific and technical activities \\
\hline $\mathrm{N}$ & Administrative and support service activities \\
\hline $\mathrm{O}$ & Public administration and defence; compulsory social security \\
\hline$P$ & Education \\
\hline Q & Human health and social work activities \\
\hline $\mathrm{R}$ & Arts, entertainment and recreation \\
\hline $\mathrm{S}$ & Other service activities \\
\hline $\mathrm{T}$ & $\begin{array}{l}\text { Activities of households as employers; undifferentiated goods- and services-producing activities of } \\
\text { households for own use }\end{array}$ \\
\hline $\mathrm{U}$ & Activities of extraterritorial organisations and bodies \\
\hline
\end{tabular}

Source: authors' construction based on UNSD (2008). 
Table A2: Aggregation of activities into sectors based on ISIC Rev. 4

\begin{tabular}{|c|c|}
\hline Sectors & Sections \\
\hline Agriculture & A \\
\hline Industry & $\mathrm{B}-\mathrm{F}$ \\
\hline Service & G-S \\
\hline Market services & G-M \\
\hline Non-business market services & $\mathrm{G}-\mathrm{J}$ \\
\hline Business market services & $\mathrm{K}-\mathrm{M}$ \\
\hline Non-market services & $\mathrm{N}-\mathrm{S}$ \\
\hline
\end{tabular}

Note: this table represents the aggregation of activities used in the analysis of this paper.

Source: authors' construction based on UNSD (2008).

Figure A1: Trends in employment and value-added share of manufacturing in China

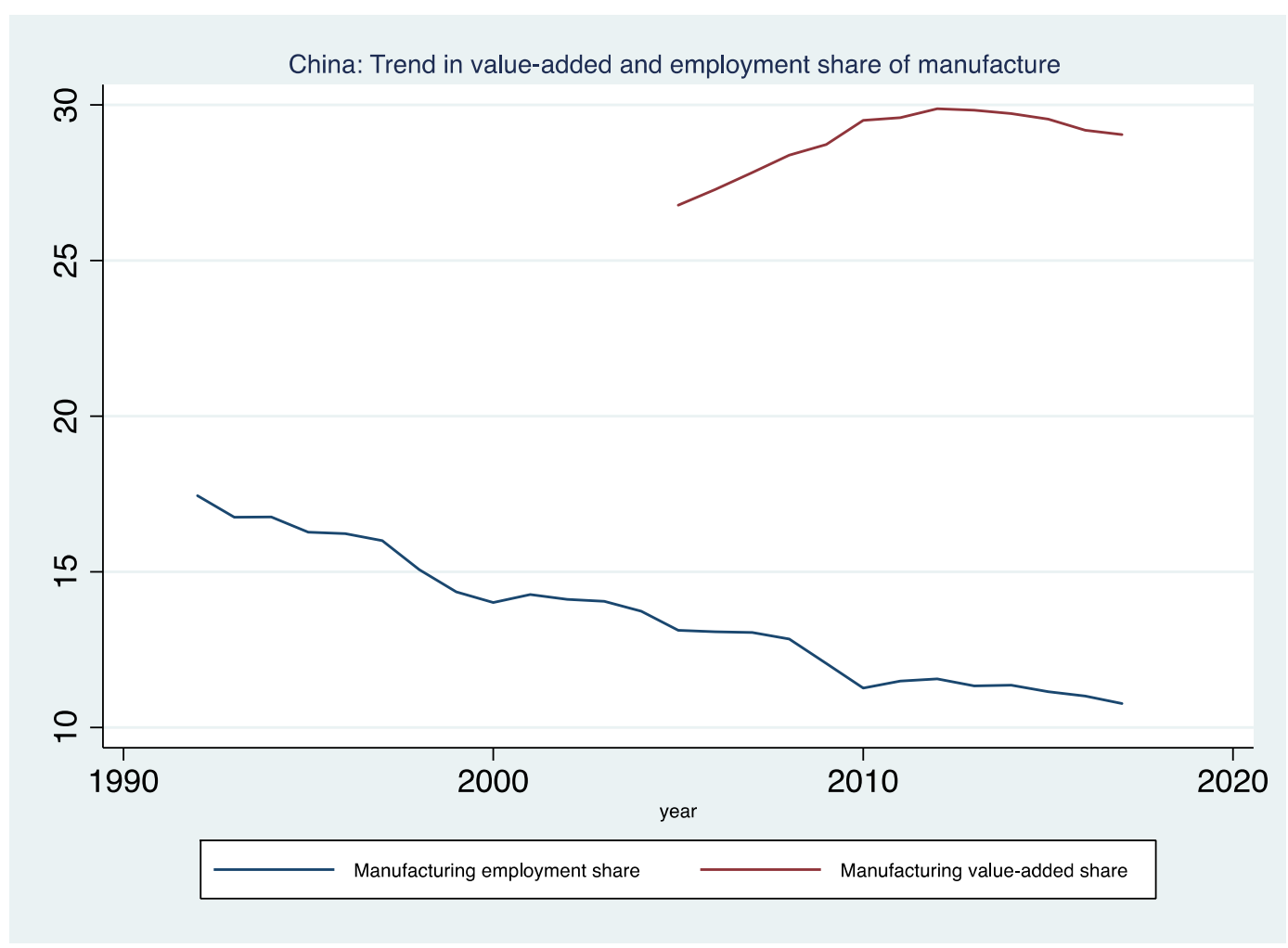

Source: authors' illustration based on ILOSTAT (2020); UNSD (2020). 
Table A3: Trends in employment and labour productivity

\begin{tabular}{|c|c|c|c|c|}
\hline $\begin{array}{r}\text { Labour } \\
\text { roductivity } \\
\text { gap }\end{array}$ & $\begin{array}{l}\text { Highest labour } \\
\text { productivity }\end{array}$ & $\begin{array}{l}\text { Lowest labour } \\
\text { productivity }\end{array}$ & $\begin{array}{l}\text { Highest } \\
\text { employment } \\
\text { share }\end{array}$ & $\begin{array}{l}\text { Lowest } \\
\text { employment } \\
\text { share }\end{array}$ \\
\hline
\end{tabular}

Asia

$\begin{array}{llllll}\text { Bangladesh } & 3,671.963 & \text { ind } & \text { agr } & \text { agr } & \text { ind } \\ \text { China } & 18,656.47 & \text { ind } & \text { agr } & \text { srv } & \text { agr } \\ \text { India\# } & 6,480.544 & \text { srv } & \text { agr } & \text { agr } & \text { ind } \\ \text { Indonesia } & 10,394.37 & \text { ind } & \text { agr } & \text { srv } & \text { ind } \\ \text { Iran\# } & 10,729.33 & \text { ind } & \text { agr } & \text { srv } & \text { agr } \\ \text { Jordan } & 5,922.951 & \text { ind } & \text { srv } & \text { srv } & \text { agr } \\ \text { Kazakhstan* } & 27,367.81 & \text { ind } & \text { agr } & \text { srv } & \text { agr } \\ \text { Kyrgyzstan } & \text { (1, } & \text { ind } & \text { agr } & \text { srv } & \text { ind } \\ \text { Lebanon }^{*} & 1,918.998 & \text { srv } & \text { agr } & \text { srv } & \text { agr } \\ \text { Malaysia } & 20,257.95 & \text { ind } & \text { agr } & \text { srv } & \text { agr } \\ \text { Mongolia* } & 15,729.14 & \text { ind } & \text { agr } & \text { srv } & \text { ind } \\ \text { Pakistan } & 13,990.89 & \text { srv } & \text { agr } & \text { agr } & \text { ind } \\ \text { Philippines } & 4,044.175 & \text { ind } & \text { agr } & \text { srv } & \text { ind } \\ \text { Sri Lanka } & 10,739.91 & \text { srv } & \text { agr } & \text { srv } & \text { agr } \\ \text { Thailand } & 10,331.49 & \text { ind } & \text { agr } & \text { srv } & \text { ind } \\ \text { Viet Nam } & 14,421.15 & \text { ind } & \text { agr } & \text { agr } & \text { ind }\end{array}$

Europe

Albania $^{\#}$
Armenia*
Azerbaijan
Belarus
Bulgaria
Romania
Turkey
Ukraine

$7,084.305 \quad$ ind

agr

srv

ind

$9,310.866 \quad$ ind

agr

srv

ind

$28,997.81 \quad$ ind

agr

srv

ind

4,547.638 ind

agr

srv

agr

3,951.08 srv

agr

srv

agr

21,977.15 srv

agr

srv

agr

$25,028.33$ ind

agr

srv

agr

694.9001 ind

agr

srv

agr

LAC

$\begin{array}{lrllll}\text { Argentina }^{*} & 2,983.494 & \text { agr } & \text { srv } & \text { srv } & \text { agr } \\ \text { Belize }^{*} & 4,528.811 & \text { srv } & \text { agr } & \text { srv } & \text { ind } \\ \text { Bolivia }^{*} & 6,502.74 & \text { ind } & \text { agr } & \text { srv } & \text { ind } \\ \text { Brazil }^{*} & 8,108.011 & \text { ind } & \text { agr } & \text { srv } & \text { agr } \\ \text { Colombia* }^{*} & 13,271.81 & \text { ind } & \text { agr } & \text { srv } & \text { agr }\end{array}$




\begin{tabular}{|c|c|c|c|c|c|c|}
\hline & Costa Rica* & $17,940.52$ & ind & agr & srv & agr \\
\hline & Dominican Republic ${ }^{\star}$ & $12,959.66$ & ind & agr & srv & agr \\
\hline & Ecuador $^{*}$ & $16,074.14$ & ind & agr & srv & ind \\
\hline & Guatemala & $10,265.09$ & ind & agr & srv & ind \\
\hline & Guyana* $^{*}$ & $3,891.705$ & ind & srv & srv & agr \\
\hline & Jamaica $^{*}$ & $9,055.285$ & ind & agr & srv & ind \\
\hline & Mexico* $^{*}$ & $19,592.77$ & ind & agr & srv & agr \\
\hline & Paraguay & $14,434.3$ & ind & agr & srv & ind \\
\hline & Peru* & $19,671.71$ & ind & agr & srv & ind \\
\hline \multicolumn{7}{|l|}{$\begin{array}{l}\text { Middle East } \\
\text { and North } \\
\text { Africa (MENA) }\end{array}$} \\
\hline & Algeria* $^{*}$ & $5,262.261$ & ind & srv & srv & agr \\
\hline & Egypt $^{\star}$ & $11,390.47$ & ind & agr & srv & agr \\
\hline & Morocco* & $8,655.688$ & ind & agr & srv & ind \\
\hline & Tunisia & $6,719.802$ & srv & agr & srv & agr \\
\hline \multicolumn{7}{|l|}{ SSA } \\
\hline & Botswana $^{*}$ & $19,522.09$ & ind & agr & srv & ind \\
\hline & Cameroon $^{*}$ & $4,364.468$ & ind & agr & agr & ind \\
\hline & Congo & $12,180.12$ & ind & agr & srv & ind \\
\hline & Côte d'Ivoire & $6,420.172$ & ind & agr & srv & ind \\
\hline & Gabon* $^{*}$ & $61,428.64$ & ind & agr & srv & ind \\
\hline & Ghana* $^{*}$ & $4,969.76$ & ind & agr & srv & ind \\
\hline & Kenya* $^{*}$ & $6,440.827$ & ind & agr & agr & ind \\
\hline & Mauritania & $13,389.21$ & ind & agr & agr & ind \\
\hline & Namibia* & $28,680.39$ & ind & agr & srv & ind \\
\hline & Nigeria* $^{*}$ & $8,672.065$ & ind & agr & srv & ind \\
\hline & South Africa* & $13,225.93$ & ind & agr & srv & agr \\
\hline & Zimbabwe $^{*}$ & $11,178.03$ & ind & agr & agr & ind \\
\hline
\end{tabular}

Note: agr, ind, and srv denote the sectors agriculture, industry, and services, respectively. There are 54 middleincome countries on this list. * denotes countries that face premature deindustrialization through the approach discussed in Section 2 (with conditions 1 to 5). ${ }^{\#}$ represents countries added to the premature deindustrialization list in addition to those defined by ${ }^{*}$ when we change the definition for deindustrialization by considering only employment share of manufacturing, excluding value-added share (i.e. conditions $1,3,4$, and 5 as discussed in Section 2).

Source: authors' construction based on ILOSTAT (2020); UNSD (2020). 
Table A4: List of countries facing premature deindustrialization (considering both employment and value-added share of manufacture for deindustrialization)

\begin{tabular}{|c|c|c|c|c|c|c|}
\hline Country & $\begin{array}{l}\text { Year } \\
(\mathrm{t})\end{array}$ & $\begin{array}{r}\text { Employment } \\
\text { share of } \\
\text { manufacturing } \\
(\mathrm{t}-\mathrm{n}, \mathrm{t})\end{array}$ & $\begin{array}{r}\text { Employment } \\
\text { share of } \\
\text { manufacturing } \\
(\mathrm{t}, \mathrm{t}+\mathrm{n})\end{array}$ & $\begin{array}{r}\text { Value-added } \\
\text { share of } \\
\text { manufacturing } \\
(\mathrm{t}-\mathrm{n}, \mathrm{t})\end{array}$ & $\begin{array}{r}\text { Value-added } \\
\text { share of } \\
\text { manufacturing } \\
(\mathrm{t}, \mathrm{t}+\mathrm{n})\end{array}$ & $\begin{array}{r}\text { GDP per capita } \\
\text { (2015 constant } \\
\text { US\$) }\end{array}$ \\
\hline \multirow[t]{7}{*}{ Albania\# } & 1999 & 0.083 & 0.075 & 0.037 & 0.048 & $1,813.76$ \\
\hline & 2000 & 0.081 & 0.074 & 0.037 & 0.051 & 1935.69 \\
\hline & 2001 & 0.08 & 0.073 & 0.037 & 0.052 & $2,095.91$ \\
\hline & 2002 & 0.079 & 0.074 & 0.039 & 0.054 & $2,193.46$ \\
\hline & 2003 & 0.078 & 0.075 & 0.041 & 0.056 & $2,320.79$ \\
\hline & 2004 & 0.077 & 0.075 & 0.043 & 0.058 & $2,459.13$ \\
\hline & 2005 & 0.076 & 0.075 & 0.046 & 0.059 & $2,610.24$ \\
\hline \multirow[t]{4}{*}{ Algeria } & 2002 & 0.185 & 0.153 & 0.049 & 0.045 & $3,297.60$ \\
\hline & 2004 & 0.179 & 0.145 & 0.047 & 0.044 & $3,592.60$ \\
\hline & 2005 & 0.175 & 0.141 & 0.047 & 0.045 & $3,752.10$ \\
\hline & 2006 & 0.17 & 0.136 & 0.046 & 0.045 & $3,760.20$ \\
\hline \multirow[t]{3}{*}{ Argentina } & 2000 & 0.176 & 0.14 & 0.18 & 0.173 & $11,635.50$ \\
\hline & 2001 & 0.166 & 0.14 & 0.178 & 0.174 & $11,001.70$ \\
\hline & 2002 & 0.156 & 0.139 & 0.176 & 0.176 & $9,697.50$ \\
\hline \multirow[t]{9}{*}{ Armenia } & 1999 & 0.082 & 0.074 & 0.134 & 0.107 & $1,191.70$ \\
\hline & 2000 & 0.081 & 0.073 & 0.126 & 0.105 & $1,270.00$ \\
\hline & 2001 & 0.079 & 0.071 & 0.111 & 0.102 & $1,400.00$ \\
\hline & 2002 & 0.078 & 0.07 & 0.109 & 0.101 & $1,619.50$ \\
\hline & 2003 & 0.077 & 0.067 & 0.108 & 0.1 & $1,856.70$ \\
\hline & 2004 & 0.076 & 0.067 & 0.108 & 0.1 & $2,062.90$ \\
\hline & 2005 & 0.075 & 0.067 & 0.108 & 0.098 & $2,364.20$ \\
\hline & 2006 & 0.074 & 0.069 & 0.107 & 0.098 & $2,697.00$ \\
\hline & 2007 & 0.073 & 0.071 & 0.105 & 0.099 & $3,094.70$ \\
\hline \multirow[t]{7}{*}{ Azerbaijan } & 1999 & 0.049 & 0.046 & 0.104 & 0.089 & $1,353.50$ \\
\hline & 2000 & 0.049 & 0.046 & 0.102 & 0.085 & $1,491.00$ \\
\hline & 2001 & 0.048 & 0.046 & 0.098 & 0.08 & $1,623.70$ \\
\hline & 2002 & 0.047 & 0.047 & 0.096 & 0.075 & $1,759.80$ \\
\hline & 2003 & 0.047 & 0.047 & 0.094 & 0.069 & 1919.90 \\
\hline & 2004 & 0.047 & 0.047 & 0.094 & 0.064 & $2,075.80$ \\
\hline & 2005 & 0.047 & 0.047 & 0.092 & 0.059 & $2,628.40$ \\
\hline Belize & 1999 & 0.108 & 0.095 & 0.121 & 0.112 & $3,928.70$ \\
\hline
\end{tabular}




\begin{tabular}{|c|c|c|c|c|c|c|}
\hline & 2000 & 0.106 & 0.096 & 0.12 & 0.115 & $4,290.70$ \\
\hline & 2001 & 0.104 & 0.096 & 0.118 & 0.117 & 4,355.10 \\
\hline & 2009 & 0.096 & 0.086 & 0.124 & 0.119 & $4,718.90$ \\
\hline & 2010 & 0.095 & 0.083 & 0.129 & 0.107 & $4,742.90$ \\
\hline \multirow[t]{3}{*}{ Bolivia } & 1999 & 0.117 & 0.108 & 0.126 & 0.126 & $2,048.00$ \\
\hline & 2008 & 0.109 & 0.106 & 0.127 & 0.127 & $2,415.00$ \\
\hline & 2009 & 0.113 & 0.104 & 0.128 & 0.127 & $2,454.80$ \\
\hline \multirow[t]{6}{*}{ Botswana } & 1999 & 0.092 & 0.091 & 0.057 & 0.056 & $4,657.10$ \\
\hline & 2000 & 0.092 & 0.088 & 0.058 & 0.056 & $4,654.10$ \\
\hline & 2001 & 0.093 & 0.086 & 0.059 & 0.055 & $4,578.40$ \\
\hline & 2002 & 0.094 & 0.082 & 0.06 & 0.056 & $4,770.90$ \\
\hline & 2003 & 0.095 & 0.079 & 0.06 & 0.057 & $4,906.00$ \\
\hline & 2004 & 0.096 & 0.075 & 0.059 & 0.059 & $4,949.90$ \\
\hline \multirow[t]{12}{*}{ Brazil } & 1999 & 0.148 & 0.139 & 0.161 & 0.156 & $6,639.00$ \\
\hline & 2000 & 0.146 & 0.14 & 0.161 & 0.157 & $6,827.00$ \\
\hline & 2001 & 0.144 & 0.14 & 0.16 & 0.157 & $6,822.70$ \\
\hline & 2002 & 0.142 & 0.14 & 0.158 & 0.156 & $6,912.70$ \\
\hline & 2003 & 0.141 & 0.14 & 0.157 & 0.154 & $6,904.60$ \\
\hline & 2004 & 0.139 & 0.139 & 0.156 & 0.153 & $7,206.30$ \\
\hline & 2005 & 0.139 & 0.138 & 0.156 & 0.149 & $7,352.30$ \\
\hline & 2006 & 0.139 & 0.136 & 0.156 & 0.146 & $7,560.70$ \\
\hline & 2007 & 0.14 & 0.134 & 0.157 & 0.143 & $7,936.80$ \\
\hline & 2008 & 0.14 & 0.132 & 0.157 & 0.139 & $8,258.60$ \\
\hline & 2009 & 0.14 & 0.128 & 0.156 & 0.134 & $8,169.30$ \\
\hline & 2010 & 0.14 & 0.125 & 0.154 & 0.131 & $8,702.30$ \\
\hline \multirow[t]{9}{*}{ Cameroon } & 1999 & 0.082 & 0.082 & 0.169 & 0.168 & $1,045.70$ \\
\hline & 2003 & 0.082 & 0.082 & 0.164 & 0.164 & $1,108.10$ \\
\hline & 2004 & 0.082 & 0.082 & 0.163 & 0.163 & $1,151.80$ \\
\hline & 2005 & 0.082 & 0.081 & 0.166 & 0.166 & $1,143.70$ \\
\hline & 2006 & 0.082 & 0.081 & 0.168 & 0.167 & $1,151.40$ \\
\hline & 2007 & 0.082 & 0.08 & 0.17 & 0.166 & $1,175.20$ \\
\hline & 2008 & 0.082 & 0.078 & 0.168 & 0.164 & $1,183.20$ \\
\hline & 2009 & 0.082 & 0.075 & 0.167 & 0.164 & $1,176.40$ \\
\hline & 2010 & 0.082 & 0.072 & 0.164 & 0.164 & $1,183.60$ \\
\hline Colombia & 1999 & 0.037 & 0.035 & 0.055 & 0.046 & $3,911.60$ \\
\hline Costa Rica & 2006 & 0.081 & 0.081 & 0.089 & 0.055 & $8,934.40$ \\
\hline
\end{tabular}




\begin{tabular}{|c|c|c|c|c|c|c|}
\hline & 2007 & 0.081 & 0.081 & 0.085 & 0.053 & $9,534.20$ \\
\hline \multirow{3}{*}{$\begin{array}{l}\text { Dominican } \\
\text { Republic }\end{array}$} & 2001 & 0.045 & 0.045 & 0.118 & 0.117 & $3,949.60$ \\
\hline & 2009 & 0.045 & 0.044 & 0.124 & 0.119 & $5,180.90$ \\
\hline & 2010 & 0.045 & 0.044 & 0.129 & 0.107 & $5,544.40$ \\
\hline \multirow[t]{3}{*}{ Ecuador } & 1999 & 0.185 & 0.155 & 0.126 & 0.126 & $4,243.90$ \\
\hline & 2009 & 0.141 & 0.104 & 0.128 & 0.127 & $5,224.80$ \\
\hline & 2010 & 0.136 & 0.103 & 0.129 & 0.127 & $5,323.70$ \\
\hline \multirow[t]{4}{*}{ Egypt } & 1999 & 0.111 & 0.102 & 0.057 & 0.056 & $2,419.00$ \\
\hline & 2000 & 0.109 & 0.103 & 0.058 & 0.056 & $2,500.50$ \\
\hline & 2001 & 0.108 & 0.103 & 0.059 & 0.055 & $2,539.80$ \\
\hline & 2002 & 0.107 & 0.105 & 0.06 & 0.056 & $2,571.90$ \\
\hline \multirow[t]{2}{*}{ Gabon } & 2008 & 0.185 & 0.147 & 0.147 & 0.147 & $6,857.70$ \\
\hline & 2009 & 0.18 & 0.143 & 0.148 & 0.147 & $6,629.70$ \\
\hline \multirow[t]{5}{*}{ Ghana } & 2006 & 0.024 & 0.024 & 0.168 & 0.167 & $1,212.80$ \\
\hline & 2007 & 0.024 & 0.024 & 0.17 & 0.166 & $1,233.30$ \\
\hline & 2008 & 0.024 & 0.024 & 0.168 & 0.164 & $1,311.90$ \\
\hline & 2009 & 0.024 & 0.023 & 0.167 & 0.164 & $1,340.90$ \\
\hline & 2010 & 0.024 & 0.023 & 0.164 & 0.164 & $1,411.30$ \\
\hline \multirow[t]{12}{*}{ Guyana } & 1999 & 0.15 & 0.135 & 0.121 & 0.081 & $2,694.10$ \\
\hline & 2000 & 0.148 & 0.133 & 0.118 & 0.074 & $2,667.50$ \\
\hline & 2001 & 0.146 & 0.13 & 0.116 & 0.068 & $2,733.10$ \\
\hline & 2002 & 0.144 & 0.127 & 0.108 & 0.062 & $2,763.30$ \\
\hline & 2003 & 0.142 & 0.123 & 0.1 & 0.062 & $2,734.30$ \\
\hline & 2004 & 0.14 & 0.119 & 0.093 & 0.062 & $2,822.10$ \\
\hline & 2005 & 0.138 & 0.114 & 0.086 & 0.062 & $2,765.30$ \\
\hline & 2006 & 0.135 & 0.11 & 0.081 & 0.061 & $2,906.40$ \\
\hline & 2007 & 0.133 & 0.105 & 0.074 & 0.061 & $3,114.90$ \\
\hline & 2008 & 0.13 & 0.101 & 0.068 & 0.061 & $3,168.10$ \\
\hline & 2009 & 0.127 & 0.098 & 0.062 & 0.06 & $3,278.60$ \\
\hline & 2010 & 0.123 & 0.096 & 0.062 & 0.06 & $3,406.40$ \\
\hline \multirow[t]{6}{*}{ India" } & 1999 & 0.069 & 0.067 & 0.143 & 0.147 & 757.90 \\
\hline & 2000 & 0.069 & 0.067 & 0.145 & 0.149 & 773.22 \\
\hline & 2001 & 0.069 & 0.067 & 0.146 & 0.151 & 796.63 \\
\hline & 2002 & 0.069 & 0.067 & 0.147 & 0.154 & 813.08 \\
\hline & 2003 & 0.068 & 0.067 & 0.146 & 0.157 & 862.62 \\
\hline & 2004 & 0.067 & 0.066 & 0.145 & 0.159 & 916.05 \\
\hline
\end{tabular}




\begin{tabular}{|c|c|c|c|c|c|c|}
\hline & 2005 & 0.067 & 0.066 & 0.145 & 0.161 & 973.14 \\
\hline & 2006 & 0.067 & 0.065 & 0.147 & 0.163 & $1,035.45$ \\
\hline & 2007 & 0.067 & 0.065 & 0.149 & 0.163 & $1,098.08$ \\
\hline & 2008 & 0.067 & 0.064 & 0.151 & 0.165 & $1,115.51$ \\
\hline & 2009 & 0.067 & 0.064 & 0.154 & 0.166 & $1,186.36$ \\
\hline & 2010 & 0.067 & 0.064 & 0.157 & 0.166 & $1,269.90$ \\
\hline \multirow[t]{5}{*}{$\operatorname{Iran}^{\#}$} & 2001 & 0.127 & 0.126 & 0.077 & 0.104 & $3,982.13$ \\
\hline & 2002 & 0.127 & 0.124 & 0.081 & 0.106 & $4,247.16$ \\
\hline & 2003 & 0.127 & 0.123 & 0.086 & 0.109 & $4,547.52$ \\
\hline & 2004 & 0.126 & 0.124 & 0.09 & 0.112 & $4,643.73$ \\
\hline & 2006 & 0.127 & 0.127 & 0.094 & 0.115 & $4,917.09$ \\
\hline \multirow[t]{12}{*}{ Jamaica } & 1999 & 0.168 & 0.14 & 0.135 & 0.106 & $4,917.74$ \\
\hline & 2000 & 0.166 & 0.134 & 0.13 & 0.103 & $4,910.66$ \\
\hline & 2001 & 0.164 & 0.129 & 0.125 & 0.101 & $4,936.40$ \\
\hline & 2002 & 0.16 & 0.124 & 0.12 & 0.099 & $4,936.20$ \\
\hline & 2003 & 0.155 & 0.12 & 0.116 & 0.097 & $5,085.80$ \\
\hline & 2004 & 0.153 & 0.117 & 0.112 & 0.095 & $5,123.70$ \\
\hline & 2005 & 0.148 & 0.114 & 0.109 & 0.094 & $5,141.20$ \\
\hline & 2006 & 0.14 & 0.112 & 0.106 & 0.093 & $5,262.60$ \\
\hline & 2007 & 0.134 & 0.111 & 0.103 & 0.092 & $5,312.00$ \\
\hline & 2008 & 0.129 & 0.11 & 0.101 & 0.092 & $5,243.00$ \\
\hline & 2009 & 0.124 & 0.109 & 0.099 & 0.091 & $4,990.10$ \\
\hline & 2010 & 0.12 & 0.108 & 0.097 & 0.091 & $4,891.80$ \\
\hline \multirow[t]{9}{*}{ Kazakhstan } & 2000 & 0.096 & 0.068 & 0.126 & 0.126 & $4,380.40$ \\
\hline & 2001 & 0.091 & 0.067 & 0.127 & 0.123 & $4,978.00$ \\
\hline & 2002 & 0.087 & 0.066 & 0.128 & 0.12 & $5,439.30$ \\
\hline & 2003 & 0.082 & 0.066 & 0.128 & 0.119 & $5,898.00$ \\
\hline & 2004 & 0.077 & 0.066 & 0.129 & 0.118 & $6,399.90$ \\
\hline & 2005 & 0.074 & 0.066 & 0.128 & 0.116 & $6,951.00$ \\
\hline & 2006 & 0.071 & 0.066 & 0.127 & 0.115 & $7,621.70$ \\
\hline & 2007 & 0.068 & 0.066 & 0.126 & 0.113 & $8,219.50$ \\
\hline & 2008 & 0.067 & 0.066 & 0.123 & 0.112 & $8,403.90$ \\
\hline \multirow[t]{3}{*}{ Kenya } & 2008 & 0.137 & 0.135 & 0.117 & 0.108 & $1,097.80$ \\
\hline & 2009 & 0.138 & 0.133 & 0.117 & 0.106 & $1,103.30$ \\
\hline & 2010 & 0.139 & 0.133 & 0.116 & 0.103 & $1,163.90$ \\
\hline Kyrgyzstan & 2009 & 0.186 & 0.17 & 0.205 & 0.168 & 991.30 \\
\hline
\end{tabular}




\begin{tabular}{|c|c|c|c|c|c|c|}
\hline \multirow[t]{3}{*}{ Lebanon } & 2008 & 0.185 & 0.169 & 0.103 & 0.1 & $8,105.20$ \\
\hline & 2009 & 0.181 & 0.169 & 0.103 & 0.096 & $8,830.70$ \\
\hline & 2010 & 0.178 & 0.17 & 0.104 & 0.093 & $9,270.70$ \\
\hline Mexico & 2009 & 0.117 & 0.107 & 0.191 & 0.182 & $8,563.30$ \\
\hline \multirow[t]{2}{*}{ Mongolia } & 2009 & 0.05 & 0.048 & 0.109 & 0.091 & $2,543.00$ \\
\hline & 2010 & 0.05 & 0.046 & 0.106 & 0.09 & $2,659.00$ \\
\hline \multirow[t]{6}{*}{ Morocco } & 2004 & 0.182 & 0.169 & 0.187 & 0.171 & $1,973.20$ \\
\hline & 2005 & 0.181 & 0.166 & 0.184 & 0.17 & $2,009.30$ \\
\hline & 2006 & 0.179 & 0.163 & 0.181 & 0.168 & $2,140.70$ \\
\hline & 2007 & 0.179 & 0.159 & 0.179 & 0.169 & $2,173.30$ \\
\hline & 2008 & 0.178 & 0.157 & 0.176 & 0.17 & $2,274.80$ \\
\hline & 2009 & 0.175 & 0.155 & 0.172 & 0.172 & $2,448.30$ \\
\hline \multirow[t]{5}{*}{ Namibia } & 1999 & 0.068 & 0.067 & 0.129 & 0.129 & $3,095.80$ \\
\hline & 2007 & 0.067 & 0.066 & 0.13 & 0.13 & $4,042.60$ \\
\hline & 2008 & 0.067 & 0.065 & 0.131 & 0.126 & $4,074.80$ \\
\hline & 2009 & 0.067 & 0.065 & 0.132 & 0.123 & $4,012.90$ \\
\hline & 2010 & 0.066 & 0.065 & 0.133 & 0.12 & $4,179.30$ \\
\hline Nigeria & 2009 & 0.197 & 0.17 & 0.085 & 0.083 & $2,322.30$ \\
\hline Pakistan & 2010 & 0.111 & 0.088 & 0.134 & 0.134 & $1,222.80$ \\
\hline \multirow[t]{4}{*}{ Peru } & 2007 & 0.146 & 0.118 & 0.169 & 0.168 & $4,437.30$ \\
\hline & 2008 & 0.142 & 0.116 & 0.172 & 0.164 & $4,803.40$ \\
\hline & 2009 & 0.137 & 0.112 & 0.173 & 0.16 & $4,817.20$ \\
\hline & 2010 & 0.132 & 0.11 & 0.173 & 0.157 & $5,176.30$ \\
\hline \multirow[t]{12}{*}{ South Africa } & 1999 & 0.156 & 0.146 & 0.152 & 0.152 & $4,384.60$ \\
\hline & 2000 & 0.155 & 0.144 & 0.153 & 0.153 & $4,502.90$ \\
\hline & 2001 & 0.154 & 0.142 & 0.153 & 0.152 & $4,564.80$ \\
\hline & 2002 & 0.153 & 0.14 & 0.154 & 0.15 & $4,672.70$ \\
\hline & 2003 & 0.151 & 0.138 & 0.153 & 0.148 & $4,752.00$ \\
\hline & 2004 & 0.149 & 0.137 & 0.153 & 0.147 & $4,908.30$ \\
\hline & 2005 & 0.148 & 0.136 & 0.152 & 0.146 & $5,103.80$ \\
\hline & 2006 & 0.146 & 0.134 & 0.152 & 0.144 & $5,322.10$ \\
\hline & 2007 & 0.144 & 0.133 & 0.153 & 0.142 & $5,535.40$ \\
\hline & 2008 & 0.142 & 0.131 & 0.152 & 0.14 & $5,636.40$ \\
\hline & 2009 & 0.14 & 0.13 & 0.15 & 0.138 & $5,473.00$ \\
\hline & 2010 & 0.138 & 0.128 & 0.148 & 0.137 & $5,557.90$ \\
\hline Turkey\# & 1999 & 0.155 & 0.151 & 0.164 & 0.169 & $6,198.53$ \\
\hline
\end{tabular}




\begin{tabular}{|c|c|c|c|c|c|c|}
\hline & 2000 & 0.154 & 0.151 & 0.166 & 0.171 & $6,510.52$ \\
\hline & 2001 & 0.154 & 0.151 & 0.166 & 0.173 & $6,031.54$ \\
\hline & 2002 & 0.154 & 0.151 & 0.167 & 0.174 & $6,325.47$ \\
\hline & 2003 & 0.153 & 0.15 & 0.167 & 0.177 & $6,584.80$ \\
\hline & 2004 & 0.152 & 0.15 & 0.168 & 0.18 & $7,120.57$ \\
\hline & 2005 & 0.151 & 0.15 & 0.168 & 0.182 & $7,660.09$ \\
\hline & 2009 & 0.151 & 0.15 & 0.169 & 0.183 & $7,884.57$ \\
\hline & 2010 & 0.15 & 0.15 & 0.171 & 0.184 & $8,434.84$ \\
\hline \multirow[t]{2}{*}{ Ukraine } & 2009 & 0.033 & 0.032 & 0.193 & 0.16 & $2,216.10$ \\
\hline & 2010 & 0.033 & 0.032 & 0.192 & 0.157 & $2,230.80$ \\
\hline \multirow[t]{12}{*}{ Zimbabwe } & 1999 & 0.11 & 0.106 & 0.183 & 0.151 & 953.80 \\
\hline & 2000 & 0.11 & 0.105 & 0.177 & 0.15 & 871.60 \\
\hline & 2001 & 0.109 & 0.104 & 0.171 & 0.149 & 866.80 \\
\hline & 2002 & 0.109 & 0.103 & 0.165 & 0.145 & 813.20 \\
\hline & 2003 & 0.108 & 0.102 & 0.161 & 0.148 & 750.80 \\
\hline & 2004 & 0.108 & 0.101 & 0.156 & 0.15 & 721.20 \\
\hline & 2005 & 0.107 & 0.1 & 0.153 & 0.151 & 688.60 \\
\hline & 2006 & 0.106 & 0.099 & 0.151 & 0.15 & 659.40 \\
\hline & 2007 & 0.105 & 0.098 & 0.15 & 0.147 & 632.60 \\
\hline & 2008 & 0.104 & 0.096 & 0.149 & 0.145 & 596.60 \\
\hline & 2009 & 0.103 & 0.095 & 0.145 & 0.143 & 940.50 \\
\hline & 2010 & 0.102 & 0.094 & 0.148 & 0.144 & $1,110.40$ \\
\hline
\end{tabular}

Note: this table presents the countries facing premature deindustrialization. ${ }^{*}$ represents countries that are experiencing deindustrialization in terms of employment share of manufacturing and not in terms of value-added share of manufacturing.

Source: authors' construction based on own results. 